\title{
ISPC 2008 first editorial
}

\section{K. Ruthenberg}

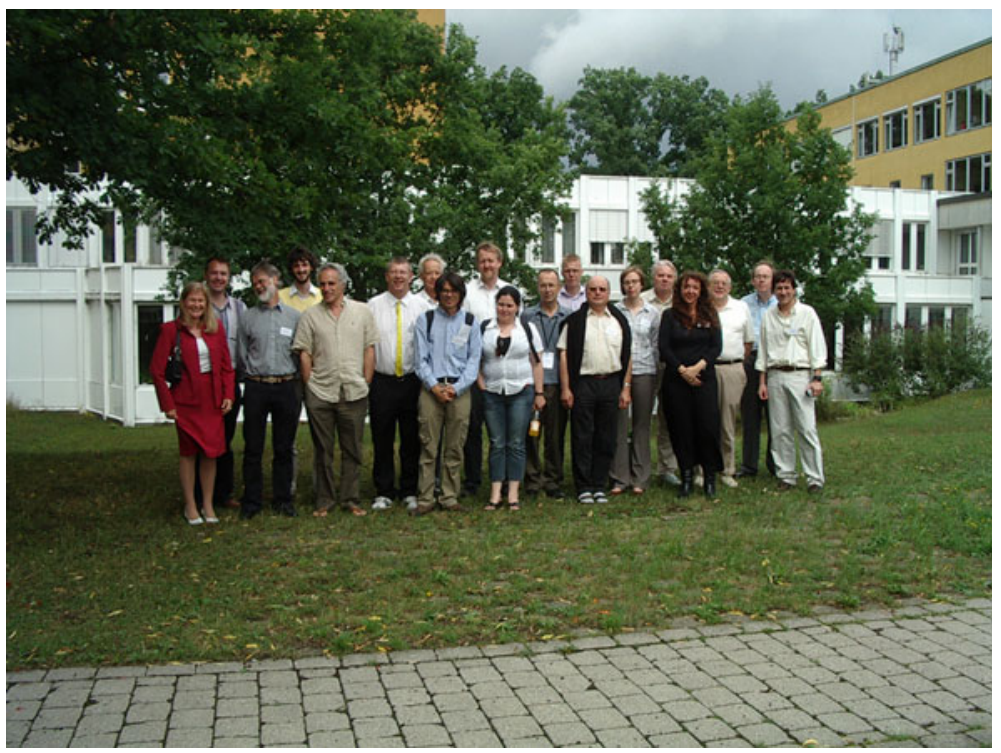

In front of the library of Coburg University of Applied Sciences. From the left: Brigitte Van Tiggelen, Robin Hendry, Paul Needham, Pieter Thyssen, Eric Scerri, Mark Leach, Jürgen Lenz, Guillermo Restrepo, Klaus Ruthenberg, Nubia Quiroz, Michael Akeroyd, Arjan Linthorst, Eugen Schwarz, Anke Timmermann, Rein Vihalemm, Olimpia Lombardi, Jerry Chandler, Jaap van Brakel, Martin Labarca (not on the picture: Jens Soentgen)

Before the ISPC came into town on August 03-06, 2008, Coburg, a small city in Northern Bavaria (more precisely Upper Franconia) with around 45,000 inhabitants, had already made entries into the book of history and philosophy of chemistry at least twice: Firstly,

K. Ruthenberg $(\bowtie)$

Coburg University of Applied Sciences, Coburg, Germany

e-mail: ruthenberg@hs-coburg.de 
the famous Andreas Libavius (1555-1617), who wrote what is sometimes called the first systematical textbook of chemistry (the "Alchemia" from 1597, which was celebrated 400 years later at my home institution, the Coburg University of Applied Sciences), in 1607 became director of the "Gymnasium Casimirianum". This institution was originally supposed to become a university and is still an institute of secondary education of some reputation. Secondly, and perhaps even more strongly tied to the philosophy of chemistry, the German Working Group on Philosophy and Chemistry (Arbeitskreis Philosophie und Chemie, APC) was founded in Coburg on June 19, $1993 .{ }^{1}$

"Chemistry is the science which looks for the explanation of natural or spontaneous and induced changes in the natures of material substances." This is the definition of chemistry of the most experienced (and battlesome) scientific realist in contemporary philosophy of science, Rom Harré, in his contribution to this special issue. In this contribution, which belongs to a series of articles on causation in chemistry, he shows that chemists like Boyle, Lavoisier and van't Hoff, as well as modern chemists hold a realist view about chemical causation. The pioneer of modern philosophy of chemistry, co-founder and long-time (and current) secretary of the ISPC, Michael Akeroyd, argues that predictions of so far unknown elements were possible independently of the periodic table by applying Döbereiner's triads. Being a "creative scepticist" - as Rom Harré has put it in this year's symposium in Oxford-Jaap van Brakel in his contribution implicitly claims to skip Fodor's physicalistic notion of "special sciences" which unfortunately has been taken for granted in philosophy of science far too long: "There is no God's-Eye-point-of-view-meta-description that gives the only true identification of events." Jens Soentgen is one of the very few people who hold a doctorate in philosophy of chemistry. Astonishingly enough he is introduced "officially" to the ISPC symposia only now. For some years he has been elaborating "stuff histories" - see his short history of carbon dioxide here-from the perspective of a modern phenomenology. The two articles from Argentinian authors belong to the discussion of what might be called "ontological pluralism". Martin Labarca and Olimpia Lombardi argue for the existence of orbitals in a non-reductionist picture of the relation between quantum mechanics and molecular chemistry. In a separate article, Olimpia Lombardi and Mario Castagnino argue against the attitude of putting the difficulties in coming to terms with "quantum ontology" on the side of chemistry. They show that reasonable difficulties show-up already for physics itself. However, whether chemistry is the science of molecules - as at least Labarca and Lombardi seem to consider-or that of substance-changes certainly needs further discussion.

In sum, 18 papers from scholars from 9 countries were presented at the symposium. Other papers that could — due to different reasons - not be presented at the meeting are, or will be, published in the present journal or elsewhere. ${ }^{2}$ In addition to the oral paper programme, we had intriguing and intense special discussion sessions on "Interrelations

\footnotetext{
1 See http://www.hyle.org/journal/issues/1/hyle1.htm. Most members of the APC founding group are still active in philosophy of chemistry, like Martin Eisvogel, Nikos Psarros, Joachim Schummer, and the author. One early result of its efforts is Philosophie der Chemie-Bestandsaufnahme und Ausblick, a book edited by Psarros, Ruthenberg and Schummer in 1996. A more recent publication will be Wald, Positivism, and Chemistry, edited by Eisvogel and Ruthenberg, which is due to be published soon.

2 Arjan Linthorst for example (please find him on the group picture) published a paper on the origins of the Green Chemistry concept in Foundations of Chemistry 12 (2010) 55-68. Rom Harré, who unfortunately could not join the meeting, agreed to publish his paper Causal Concepts in Chemistry together with the conference contributions. Jerry Chandler (see picture) published his Coburg paper as An introduction to the perplex number system in Discrete Applied Mathematics 157 (2009) 2296-2309. Mark Leach, a frequent and lively contributor to the ISPC meetings, has an inspiring website which is highly recommended: www.meta-synthesis.com.
} 
between the history and the philosophy of chemistry" (chaired by Brigitte Van Tiggelen), "Philosophy of chemistry in education" (chaired by Michael Akeroyd), and "Chemical substance" (chaired by myself). ${ }^{3}$

Besides the professional programme most participants joined a bus tour to the former border between the German Democratic Republic and the Federal Republic of Germany. This is not far away from Coburg and no longer a demarcation line but an administration line between the two now friendly parts of the united Germany called the "Bundesländer" Thuringia and Bavaria. The fall of the "wall" was obviously appreciated by all of the participants.

I have to admit that some of the papers could have been published earlier and apologize for that. In February 2009, however, out of the blue I experienced that constructivism-a stance I feel sympathetic with-has its astonishing restrictions, and I realized that body and soul must be one, and that nevertheless human beings have to care for both. This care took a little time.

\footnotetext{
3 Around the time of the symposium the book Stuff-The Nature of Chemical Substances, edited by Ruthenberg and van Brakel, was released. This book was the outcome of a workshop at the Institute of Philosophy of the Catholic University Leuven, Belgium, in July 2006. As it happens, a good part of the participants of the Coburg meeting in fact directly travelled from Leuven to Coburg, coming from another workshop on the philosophical implications of quantum chemistry. (In one of these cars an English/Swedish expert of Duhem travelled together with a Scottish micro-structuralist and a German "Kantian anti-realist". All three of them are still friends). The host of the Leuven meeting was Jaap van Brakel.
} 